\title{
EFFECT OF BIOCONTROL AGENTS ON DAMPING-OFF AND ROOT-ROT DISEASES OF QUINOA (CHENOPODIUM QUINOA WILLD) SEEDLINGS
}

\author{
Abeer E. El-Hadidy \\ Department of Plant Protection, Desert Research Center, El-Matareya, \\ Cairo, Egypt \\ E-mail: elhadidyabeer@gmail.com
}

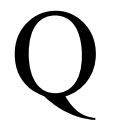

uinoa, recently introduced to Egypt and is considered as an important crop as it can grow and give considerable yield in new reclaimed salt-affected soils. Isolation trials from rotted quinoa seedlings collected in Egypt (Fayoum governorate) yielded Fusarium solani, Alternaria sp., Acremonium sp. and $F$. oxysporum. All the isolated fungi were pathogenic and caused damping-off and root-rot diseases. The efficiency of Streptomyces strains as a biocontrol agent against the pathogenic fungi was investigated under laboratory and greenhouse conditions. Streptomyces toxytricini showed the highest inhibition zone of the three strongest pathogenic fungi. S. toxytricini produced indole acetic acid (IAA) and exhibited optimum phosphate solubilization. Streptomyces strains mixtures reduced damping-off incidence, rootrot incidence and severity as well as significantly increased the number of viable seedlings under greenhouse conditions. Increase of phenolic content as well as activity of peroxidase and chitinase enzymes in Streptomyces-treated plants proved the biocontrolinduced systemic resistance in quinoa seedlings against a mixture of three pathogenic fungi; $F$. solani, Acremonium sp. and $F$. oxysporum.

Keywards: Fusarium solani, Acremonium sp., F. oxysporum, actinomycetes, quinoa seedlings

Quinoa (Chenopodium quinoa Willd), a plant belonging to family Amaranthaceae, has been cultivated in the Andean region in South America for thousands of years. Quinoa grown primarily for its edible seeds, has been introduced elsewhere as a source of starch and high-quality proteins. Because quinoa has a high nutritive value and desirable agricultural traits as tolerance to drought and salinity, it has gained increase demand recent years in Egypt under various stress conditions (Barakat et al., 2017; Eisa et al., 2017 and Mahmoud, 2017). 
Since quinoa has been introduced to Egypt a short time ago; there is little information about their associated diseases under Egyptian conditions. Downy mildew caused by the pathogen Peronospora farinosa f. sp. chenopodii is the most widespread and potentially destructive global disease of quinoa (Danielsen and Munk, 2004). There is scant knowledge about other quinoa pathogens that infect seeds or seedlings and lead to decreased crop production. These diseases are considered potential production constraints, particularly when the crop is introduced in areas outside its traditional growing regions (Danielsen et al., 2003). Root-rot and dampingoff diseases for young quinoa seedling have been detected in five different Egyptian governorates (Giza, Fayium, Ismailia, Beheira and Monufia) (ElMoity et al., 2015). Damping-off is a disease that leads to the decay of germinating seeds and young seedlings, representing one of the most important yield constraints both in nurseries and fields (Lamichhane et al., 2017). Ascochyta caulina, Fusarium avenaceum, Fusarium spp., Alternaria spp. and Pythium spp. were isolated from infected parts of quinoa seedlings and were proved that, they were the causal agents of damping-off in greenhouse experiments (Dřímalková and Veverka, 2004).

Plant disease management is done mainly by means of chemicals. Various chemical pesticides have been reported to be effective against a wide range of pathogens, but not considered as long-term solution because of concerns about health and environmental hazards, expensiveness, residue persistence, pest resurgence, and elimination of natural enemies. Therefore, the need for alternative method has become vital. The development of biological control for plant diseases is accepted as a durable and eco-friendly alternative for agrochemicals. Actinomycetes are one of the most promising sources of biocontrol agents at present gaining increased attention in the field of biological control. The secondary metabolites produced by actinomycetes play a vital role in plant growth promotion as well as suppression of pathogen growth and development in host plant (Senthilraja, 2016 and Olanrewaju and Babalola, 2019). The main aims of this study were, therefore, the identification of pathogenic fungi causing damping-off disease of quinoa seedlings, as well as seedling protection with bioagents as an ecofriendly disease management.

\section{MATERIALS AND METHODS}

\section{Source of Quinoa Seed}

Quinoa var. Real seeds were obtained from the quinoa project of Plant Department, Faculty of Agriculture, Ain Shams University, Egypt and Migual Lillo Institute, Argentina. 


\section{Isolation of Fungi Causing Damping-off Disease}

Quinoa seedlings showing the damping-off disease symptoms were collected from quinoa field under reclaimed soil conditions at Wady ElRayan, Fayoum governorate. The diseased seedlings were taken in plastic bags, brought to the laboratory for isolating the disease-causing fungi. Isolation was done from 100 small root pieces, cut from adjoining areas of diseased and healthy areas of the plants. Root pieces were washed under tap water for about $30 \mathrm{~min}$ to remove any dirt or soil particle. The root pieces were dipped in $0.5 \% \mathrm{NaCl}$ for about $2 \mathrm{~min}$ and then passed from two washes of distilled sterile water for 2-3 min each. The treated root pieces were dried completely and then transferred to Petri dishes containing sterilized potatodextrose agar (PDA) medium with five pieces per plate. All the plates were kept at $25 \pm 1^{\circ} \mathrm{C}$ for 7 days. Fresh growth of the fungi was transferred to freshly prepared PDA medium for sub culturing. The growth was subcultured/multiplied whenever needed during the entire study. Isolated fungi were identified by studying their typical mycelial growth produced on the PDA medium and conidial morphology using standard diagnostic keys. Fusarium sp. and Acremonium sp. (Cephalosporium) were frequently isolated and identified according to Booth (1971), Gams (1975) and Domsch et al. (2007), respectively. Purified isolates were maintained on PDA medium at $4^{\circ} \mathrm{C}$ for further studies.

\section{Pathogenicity Test}

The pathogenicity test for most predominant isolated fungi was done. Inoculum of each fungal isolate was prepared using barley medium in polyethylene bags, each containing $200 \mathrm{~g}$ medium as described by Singleton et al. (1992). Each fungal inoculum or mixture of them was mixed with $1 \mathrm{~kg}$ of steam sterilized sandy loam soil in plastic pots. Twenty quinoa seeds were sown per pot containing infested soil. Number of healthy and infected plants were recorded after 15 and 30 days from sowing from pots containing infested and un-infested soil.

\section{Source of Streptomyces Strains and Inoculum Preparation}

Four of Streptomyces sp. strains (21SA, 25SA, 26SA and 28SI) were obtained from Microbiology Department, Agriculture Faculty, Cairo University as well as one strain of Streptomyces toxytricini, which showed antibacterial potent in a previous study (Hassan et al., 2018).

\section{Evaluation of Streptomyces Strains In Vitro \\ 5.1. As antifungal activity}

The five strains of Streptomyces were evaluated as antifungal against Fusarium solani, F. oxysporum, and Acremonium sp, in vitro. The strains were streaked on one side of a Petri dish $(1 \mathrm{~cm}$ from the edge of the plate) with PDA medium. Eight mm diameter mycelial disc of $F$. solani, $F$. 
oxysporum and Acremonium sp. seven-days-old culture were placed on the opposite side of the Petri dish perpendicular to the bacterial streak (Vidhyasekaran et al., 1997). The plates were incubated at room temperature $\left(28^{\circ} \mathrm{C}\right)$ for 4 days and the zone of inhibition was measured. Growth inhibition percentage was calculated using the formula:

$$
\mathrm{n}=(\mathrm{a}-\mathrm{b}) / \mathrm{a} \times 100
$$

where ' $n$ ' is the growth inhibition percentage, ' $a$ ' is the fungal growth radius of a control culture (in $\mathrm{cm}$ ) and ' $\mathrm{b}$ ' is the distance of the fungal growth in the direction of actinomyces (in $\mathrm{cm}$ ). For each isolate, three replicates (plates) were maintained.

\subsection{In vitro plant growth-promoting properties of potent Streptomyces} sp.

Streptomyces strains were grown in flasks $(250 \mathrm{ml})$ containing 100 $\mathrm{ml}$ of glycerol nitrate agar media broth, for $48 \mathrm{~h}$ on a rotary shaker at $28 \pm 2^{\circ} \mathrm{C}$. Cells were removed by centrifugation at $800 \mathrm{~g}$ for $10 \mathrm{~min}$ at $4^{\circ} \mathrm{C}$ and washed in sterile water. The pellet was transferred in a small amount of sterile distilled water and then diluted with an adequate amount of sterile distilled water to obtain a bacterial suspension of $10^{8} \mathrm{cfu} \mathrm{ml}^{-1}$ (Thompson, 1996). For bacterization of quinoa seeds were surface sterilized with $2 \%$ sodium hypochlorite solution for $30 \mathrm{~s}$ and rinsed in sterile distilled water and dried overnight under a sterile air steam. Ten milliliters of bacterial inoculum $\left(10^{8} \mathrm{cfu} \mathrm{\textrm {ml } ^ { - 1 } )}\right.$ were put in a Petri dish. Then, $100 \mathrm{mg}$ of carboxymethylcellulose was added as adhesive material. One gram of quinoa seeds was soaked in $10 \mathrm{ml}$ of bacterial suspension for $12 \mathrm{~h}$ and dried overnight in sterile Petri dish. Plant growth-promoting activity of bacterial isolates was assessed based on the seedling vigor index by the standard roll towel method (ISTA, 1993). The vigor index was calculated by using the formula as described by Abdul Baki and Anderson (1973):

Vigor index $=($ Mean root length + Mean shoot length $) \times$ Germination $(\%)$

\section{Indole Acetic Acid Production}

The five strains were investigated for their ability to produce indole acetic acid (IAA). Each isolate was grown on glycerol nitrate agar broth medium containing trptophan $(1.0 \mathrm{mg} / \mathrm{L})$ and incubated in a shaker at $30^{\circ} \mathrm{C}$ and $160 \mathrm{rpm}$ for $48 \mathrm{~h}$. Next, bacterial culture was centrifuged at $10000 \mathrm{rpm}$ for $15 \mathrm{~min}$, and $1 \mathrm{ml}$ of culture filtrate was mixed with $1 \mathrm{ml}$ of Salkowskis reagent $\left(1.5 \mathrm{ml}\right.$ of $\mathrm{FeCl}_{3} .6 \mathrm{H}_{2} \mathrm{O} 0.5 \mathrm{M}$ solution, in $80 \mathrm{ml}$ of $\left.60 \% \mathrm{H}_{2} \mathrm{SO}_{4}\right)$ and the mixture was incubated at room temperature for $30 \mathrm{~min}$, presence of pink color indicates that isolate can produce IAA. Meanwhile, IAA concentration for each tested strain was quantified spectrophotometrically at $550 \mathrm{~nm}$ by comparing with IAA standard curve (Gordon and Weler, 1951).

\section{Phosphate Solubilization}

Capacity of five strains to solubilize phosphate in the form of 
calcium phosphate was checked qualitatively by using glucose yeast extract agar (GYA) medium containing per $1 \mathrm{~L}$ distilled water; $10 \mathrm{~g}$ glucose; $2 \mathrm{~g}$ yeast extract and $15 \mathrm{~g}$ agar. In addition, two other solutions were prepared separately; first $5 \mathrm{~g} \mathrm{~K}_{2} \mathrm{HPO}_{4}$ was dissolved in $50 \mathrm{ml}$ distilled water and second $10 \mathrm{~g} \mathrm{CaCl}_{2}$ in $100 \mathrm{ml}$ distilled water. These two solutions were added to 1 L CYA just before pouring medium to plates (Beneduzi et al., 2008). Each isolate was grown in GY broth for $24 \mathrm{~h}$., and then $10 \mathrm{ml}$ of bacterial culture were dropped in each plate and inculcated for 7 days at $28^{\circ} \mathrm{C}$. Isolates which showed clear halos around their colonies were considered as phosphate solubilization.

\section{Potential of Streptomyces Strains to Elicit Systemic Resistance Against Damping-off and Root-rot Diseases}

A series of greenhouse experiment was conducted to induce resistance against damping-off pathogens by using Streptomyces strains. Treatments were arranged in a randomized complete block design with eight replications consisting of ten seeds per treatment. The following treatments were included in the experiment: (1) seeds treated with Streptomyces strains; (2) seeds treated with Streptomyces strains and challenge inoculated with mixture of Fusarium solani, F. oxysporum, and Acremonium sp., 15 days after planting (50 g sand-maize medium containing $10^{3} \mathrm{cfu}^{-1}$ medium in each pot); (3) plants inoculated with the pathogens 15 days after sowing; and (4) non-treated plants. Pots with sterilized potting soil were sown with 15 seeds per each pot. Three replications were maintained in each treatment; each replicate consisted of eight pots and kept in the greenhouse with daily watering. The disease assessment was done periodically by examining and recording damping-off after 15 and 30 days from sowing date. Percentage of root-rot disease incidence was assessed 45 days after sowing. Disease severity (D.S.) was estimated visually by assessing necrotic regions on the roots and hypocotyls using rating scale of 0-5 described according to Filion et al. (2003).

$$
\text { D.S. }=\frac{\Sigma(\mathrm{ab}) \times 100}{\mathrm{AK}}
$$

where ' $a$ ' is the number of diseased plants having the same degree of infection, ' $b$ ' is the degree of infection, $\mathrm{A}$ is the total no. of examined plants, $\mathrm{K}$ is the highest degree of infection and D.S. is the disease severity.

Plant height and dry weight were determined. Four plants were sampled from each replication of the treatment separately for biochemical analysis. Fresh roots were washed in running tap water and homogenized with liquid nitrogen in a pre-chilled mortar and pestle. The homogenized root tissues were stored at $-70^{\circ} \mathrm{C}$. 


\section{Biochemical Changes Associated with Streptomyces Strains 9.1. Phenols determination}

Root samples $(1 \mathrm{~g})$ of quinoa plants grown in pot experiment and obtained from different treatments and control (20 days after inoculation were homogenized in $10 \mathrm{ml}$ of $80 \%$ methanol and agitated for $15 \mathrm{~min}$ at $70^{\circ} \mathrm{C}$ (Zieslin and Ben-Zaken, 1993). One $\mathrm{ml}$ of the metabolic extract was added to $5 \mathrm{ml}$ of distilled water and $250 \mu \mathrm{l}$ of Folin-Ciocalteau reagent (1N) and the solution was kept at $25^{\circ} \mathrm{C}$. The absorbance of the developed blue colour was measured using a spectrophotometer at $725 \mathrm{~nm}$. Catechol was used as the standard. The amount of phenolics was expressed as $\mu \mathrm{g}$ catechol mg protein $^{-1}$

\subsection{Enzymes activity}

\subsubsection{Peroxidase}

Root samples $(1 \mathrm{~g})$ of quinoa plants, grown in pot experiment and obtained from different treatments and control (20 days after inoculation), were homogenized in $2 \mathrm{ml}$ of $0.1 \mathrm{M}$ phosphate buffer, $\mathrm{pH} 7.0$ at $4^{\circ} \mathrm{C}$ for 15 min and the supernatant was used as enzyme source. The reaction mixture consisted of $1.5 \mathrm{ml}$ of $0.05 \mathrm{M}$ pyrogallol, $0.5 \mathrm{ml}$ of enzyme extract and 0.5 $\mathrm{ml}$ of $1 \% \mathrm{H}_{2} \mathrm{O}_{2}$. The reaction mixture was incubated at room temperature $\left(28 \pm 2^{\circ} \mathrm{C}\right)$. The changes in absorbance at $420 \mathrm{~nm}$ were recorded at $30 \mathrm{~s}$ intervals for $3 \mathrm{~min}$. The enzyme activity was expressed as changes in the absorbance $\min ^{-1} \mathrm{mg}$ protein ${ }^{-1}$ (Hammershmidt et al., 1982).

\subsubsection{Chitinase}

Root samples $(1 \mathrm{~g})$ of quinoa plants grown in pot experiment and obtained from different treatments and control (20 days after inoculation were homogenized with $0.2 \mathrm{M}$ Tris $\mathrm{HCl}$ buffer, $\mathrm{pH} 7.8$ containing $14 \mathrm{mM}$ Bmercaptoethanol at a rate of $1 / 3(\mathrm{w} / \mathrm{v})$. The homogenate was centrifuged at $3000 \mathrm{rpm}$ for $15 \mathrm{~min}$ and the supernatant was used to determine the enzyme activity, according to the colourimetric method suggested by Monreal and Reese (1969) using 1\% colloidal chitin. Chitinase activity was measured by the release of N-acetyl-D-glucosamine (NAG) from colloidal chitin, and expressed as acetylglucosamine released/g fresh weight tissue/60 min.

\section{Statistical Analysis}

Data were subjected to analysis of variance (ANOVA) and were calculated for mean separation analyzed and subjected to Duncan's multiple range tests and comparison after analysis of variance (Duncan, 1955).

\section{RESULTS AND DISCUSSION}

\section{Isolation of the Damping-off and Root-rot Causal Fungi}

Isolated fungi from infected quinoa seedlings were identified as Fusarium solani, F. oxisporum, Acrimonum sp. and Alternaria sp. Percentage of isolated fungi occurrence were recorded in fig. (1), where $F$. 
solani was the dominant pathogen with $48 \%$, followed by $F$. oxysporum with 23\%, then Acremonium sp. with 20\% and Alternaria sp. with $9 \%$.

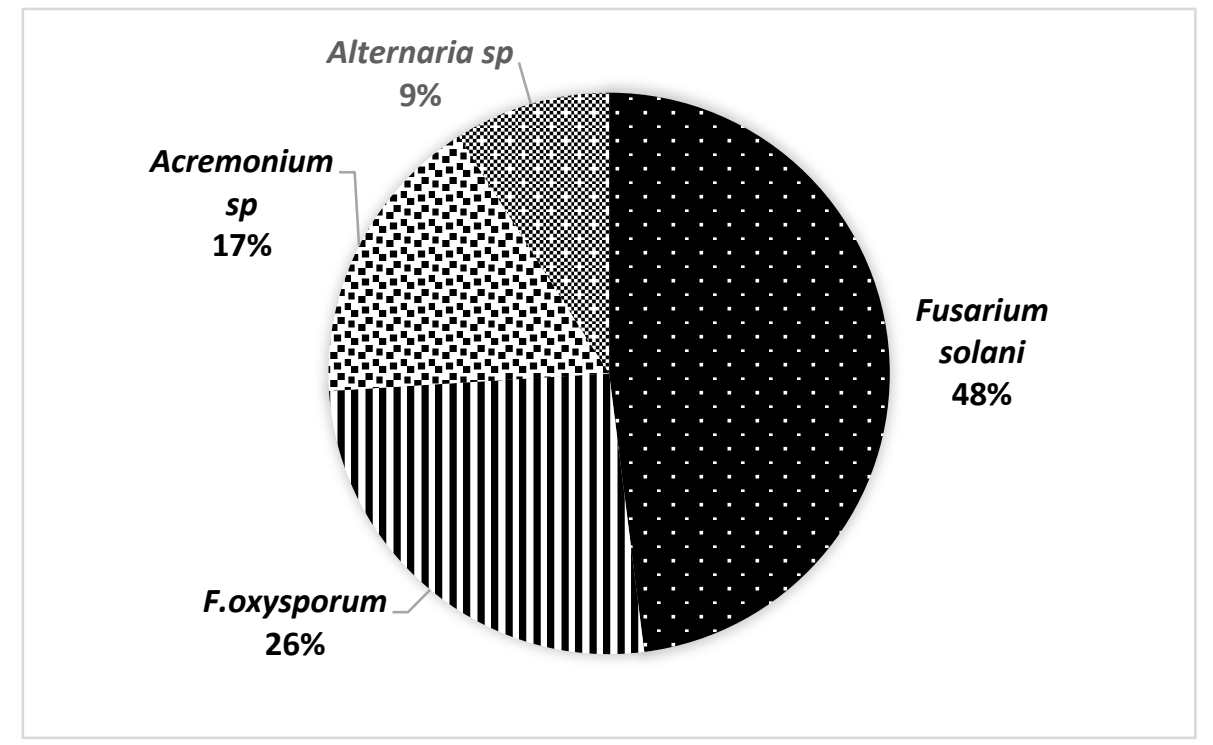

Fig. (1). Percentage of fungi isolated from quinoa seedlings grown in Wady El-Rayan, El-Fayoum governorate.

\section{Pathogenicity Test}

Results in table (1) show that all the tested fungi were pathogenic and caused pre- and post-emergence damping-off in quinoa seedlings, except Alternaria sp. didn't show pre-emergence damping-off. The mixture of isolated fungi has strongest pathogenic effect and had participated to cause disease complex. Three pathogenic fungi recorded pre- and post-emergence damping-off to quinoa seedlings with significant differences among them. $F$. oxysporum was recorded the lowest pre-emergence damping-off, whereas Alternaria sp. was recorded the lowest post-emergence damping-off for seedlings, while the highest values of pre and post damping-off were recorded with $F$. solani. The highest root-rot incidence of quinoa plants was recorded with $F$. solani after 45 days from sowing. The results agree with a previous study that refer to soil-borne pathogens; such as Rhizoctonia solani and Macrophomena phaseolina as aggressive causal organism for root-rot and damping-off diseases for young quinoa seedlings from five different Egyptian governorates (Giza, Fayium, Ismailia, Beheira and Monufia) (El-Moity et al., 2015). 
Table (1). Effect of some soil-borne fungi on the incidence of pre- and postemergence damping-off as well as survival of quinoa plants.

\begin{tabular}{ccccc}
\hline Fungal isolates & \multicolumn{2}{c}{ Damping-off (\%) } & Survival & $\begin{array}{c}\text { Root rot } \\
\text { (\%) }\end{array}$ \\
\cline { 2 - 3 } & $\begin{array}{c}\text { Pre- } \\
\text { emergence }\end{array}$ & $\begin{array}{c}\text { Post- } \\
\text { emergence }\end{array}$ & & \\
\hline Fusarium solani & $33.3 \mathrm{a}$ & $28.6 \mathrm{a}$ & $38.1 \mathrm{~d}$ & $78 \mathrm{a}$ \\
F.oxysporum & $08.7 \mathrm{c}$ & $25.1 \mathrm{~b}$ & $66.2 \mathrm{c}$ & $16 \mathrm{c}$ \\
Acremonium $s p$. & $12.5 \mathrm{~b}$ & $17.8 \mathrm{c}$ & $69.7 \mathrm{~b}$ & $32 \mathrm{~b}$ \\
Alternaria sp. & $00.0 \mathrm{~d}$ & $09.0 \mathrm{~d}$ & $91.0 \mathrm{a}$ & $11 \mathrm{~d}$ \\
\hline
\end{tabular}

\section{Evaluation of Streptomyces Strains In Vitro}

\subsection{As antifungal activity}

Among the five Streptomyces strains tested for their efficacy to inhabit the mycelial growth, three strains, Streptomyces sp. (26SA), Streptomyces sp. (25SA) and Streptomyces toxytricini exhibited the maximum inhibition for mycelial growth of $F$. solani, $F$. oxysporum and Acremonum sp. when compared with other tested strains in vitro (Table 2), due to antifungal substances released by the actinomycetes into the culture medium (Singh et al., 2017). In addition, Streptomyces sp. (25SA), Streptomyces sp. (26SA) and Streptomyces toxytricini showed the highest degree in vigor index increase of quinoa in the roll towel assay (Table 2). Actenobacteria are called plant growth-promoting rhizobacteria (PGPR). Direct promotion of plant growth by PGPR involves several mechanisms; such as production of plant growth regulators (Yang et al., 2013).

Table (2). Antagonistic effects of Streptomyces strains on the growth of $F$. solani, F. oxysporum and Acremonium sp. as well as their potential for plant growth promotion.

\begin{tabular}{lcccc}
\hline Streptomyces sp. strains & \multicolumn{3}{c}{ Inhibition zone (mm) } & \\
\cline { 2 - 4 } & F. solani & F. oxysporum & Acremonium $\mathbf{s p .}$ & $\begin{array}{c}\text { Vigor } \\
\text { index }\end{array}$ \\
\hline Streptomyces sp. (21SA) & $09.5 \mathrm{~d}$ & $13.7 \mathrm{c}$ & $14.5 \mathrm{e}$ & $1023 \mathrm{~d}$ \\
Streptomyces sp. (25SA) & $23.5 \mathrm{~b}$ & $22.4 \mathrm{~b}$ & $21.6 \mathrm{~b}$ & $1152 \mathrm{c}$ \\
Streptomyces sp. (26SA) & $25.3 \mathrm{a}$ & $22.4 \mathrm{~b}$ & $19.6 \mathrm{c}$ & $1233 \mathrm{~b}$ \\
Streptomyces sp. (28SA) & $22.9 \mathrm{c}$ & $22.4 \mathrm{~b}$ & $18.7 \mathrm{~d}$ & $1054 \mathrm{~d}$ \\
Streptomyces toxytricini & $23.7 \mathrm{~b}$ & $25.2 \mathrm{a}$ & $22.6 \mathrm{a}$ & $1435 \mathrm{a}$ \\
Untreated & $00.0 \mathrm{e}$ & $00.0 \mathrm{~d}$ & $00.0 \mathrm{f}$ & $652 \mathrm{e}$ \\
\hline
\end{tabular}

*Significant at 0.01 level of probability.

a.) Inhibition of pathogens is expressed as the distance ( $\mathrm{mm}$ ) between fungal mycelium and bacterial

colony on potato dextrose agar (PDA); each value is the mean of three replicates.

b) Vigor index $=($ Mean root length + Mean shoot length $) \times$ Germination $(\%)$ 


\subsection{As IAA production and phosphate solubilization}

All Streptomyces strains showed significant production of IAA (Table 3) that ranged from 15.4 to $38.5 \mu \mathrm{g} / \mathrm{ml}$. The strain Streptomyces toxytricini produced the highest concentration of IAA that was $38.5 \mu \mathrm{g} / \mathrm{ml}$. Moreover, three out of five strains; i.e. Streptomyces 25SA, Streptomyces 26SA and Streptomyces toxytricini showed phosphate solubilization ability. Production of growth hormone; such as IAA and solubilization phosphate by actinomycetes has also been reported by Amaresan et al. (2018).

Table (3). Determination of IAA and phosphate solubilization for Streptomyces sp. strains

\begin{tabular}{lcc}
\hline Streptomyces sp. strains & $\begin{array}{c}\text { IAA } \\
(\boldsymbol{\mu} / \mathbf{m g})\end{array}$ & $\begin{array}{c}\text { Phosphate solublition } \\
\text { ability }\end{array}$ \\
\hline Streptomyces sp. (21SA) & 15.4 & - \\
\hline Streptomyces sp. (25SA) & 35.2 & + \\
\hline Streptomyces sp. (26SA) & 30.2 & + \\
\hline Streptomyces sp. (28SA) & 19.6 & - \\
\hline Streptomyces toxytricini & 38.5 & + \\
\hline
\end{tabular}

\section{In Vivo Screening of Selected Antagonistic Isolates}

Data in table (4) indicate that five strains; i.e. Streptomyces sp. (21SA), Streptomyces sp. (25SA), Streptomyces sp. (26SA), Streptomyces sp. (28SA) and $S$. toxytricini were effective in reducing damping-off of quinoa seedlings caused by Fusarium solani, F. oxysporum and Acremonium sp. in vivo. The degree of reduction of damping-off disease varied according to Streptomyces strains and the pathogen. However, the fungicides rizolex-T seed treatment performed the best reduction in damping-off caused by the three pathogens. Data in table (4) also indicate that, there were varied effects of the tested Streptomyces strains on seedling survival in pathogen noninfested soil. S. toxytricini increased the seedling survival by $84 \%$ as well as dry weight by $17 \mathrm{mg}$. Results also indicated that the quinoa seed germination test in Petri-plates could be used for evaluation the biocontrol agents against root-rot pathogen. Actinomycetes are considered as a source of novel biocontrol and plant growth promoting agent in general (Chaurasia et al., 2018 and Vurukonda et al., 2018). 
Table (4). In vivo screening of selected antagonistic strains against $F$. solani, F. oxysporum and Acremonium sp. of quinoa and their effect on seedling dry weight.

\begin{tabular}{|c|c|c|c|c|c|c|c|c|c|c|}
\hline \multirow{3}{*}{$\begin{array}{l}\text { Streptomyces } \\
\text { sp. strains }\end{array}$} & \multicolumn{8}{|c|}{ Infested soil } & \multirow{2}{*}{\multicolumn{2}{|c|}{ Non-infested soil }} \\
\hline & \multicolumn{2}{|c|}{ F. solani } & \multicolumn{2}{|c|}{$F$. oxysporum } & \multicolumn{2}{|c|}{ Acremoinum sp. } & \multicolumn{2}{|c|}{ Mixture } & & \\
\hline & $\begin{array}{c}\text { Survived } \\
\text { seedlings } \\
(\%)\end{array}$ & $\begin{array}{c}\text { Dry } \\
\text { weight } \\
(\mathrm{mg})\end{array}$ & $\begin{array}{c}\text { Survived } \\
\text { seedlings } \\
(\%)\end{array}$ & $\begin{array}{c}\text { Dry } \\
\text { weight } \\
\text { (mg) }\end{array}$ & $\begin{array}{c}\text { Survived } \\
\text { seedlings } \\
(\%)\end{array}$ & $\begin{array}{c}\text { Dry } \\
\text { weight } \\
(\mathrm{mg})\end{array}$ & $\begin{array}{c}\text { Survived } \\
\text { seedlings } \\
(\%)\end{array}$ & $\begin{array}{c}\begin{array}{c}\text { Dry } \\
\text { weight } \\
(\mathrm{mg})\end{array} \\
\end{array}$ & $\begin{array}{c}\text { Survived } \\
\text { seedlings } \\
(\%)\end{array}$ & $\begin{array}{c}\text { Dry } \\
\text { weight } \\
(\mathrm{mg})\end{array}$ \\
\hline $\begin{array}{l}\text { Streptomyces } \\
\text { sp. (21SA) }\end{array}$ & $72 c^{*}$ & $9 \mathrm{c}$ & $78 \mathrm{~b}$ & $10 \mathrm{c}$ & $76 \mathrm{~d}$ & $12 \mathrm{~b}$ & $73 \mathrm{dc}$ & $9 \mathrm{c}$ & $78 \mathrm{~b}$ & $13 b$ \\
\hline $\begin{array}{l}\text { Streptomyces } \\
\text { sp. (25SA) }\end{array}$ & $82 b^{*}$ & $15 \mathrm{a}$ & $82 \mathrm{ab}$ & $16 \mathrm{a}$ & $84 b$ & $14 \mathrm{a}$ & $80 \mathrm{~b}$ & $14 \mathrm{a}$ & $81 \mathrm{ab}$ & $15 \mathrm{ab}$ \\
\hline $\begin{array}{l}\text { Streptomyces } \\
\text { sp. (26SA) }\end{array}$ & $81 \mathrm{~b}$ & $11 \mathrm{~b}$ & $84 a$ & $13 b$ & $83 b$ & $15 \mathrm{a}$ & $76 \mathrm{c}$ & $11 b$ & $84 a$ & $16 \mathrm{a}$ \\
\hline $\begin{array}{l}\text { Streptomyces } \\
\text { sp. (28SA) }\end{array}$ & $70 \mathrm{c}$ & $8 \mathrm{c}$ & $75 \mathrm{c}$ & $11 \mathrm{c}$ & $78 \mathrm{~d}$ & $12 b$ & $69 \mathrm{e}$ & $8 \mathrm{c}$ & $78 b$ & $12 \mathrm{~b}$ \\
\hline $\begin{array}{l}\text { Streptomyces } \\
\text { toxytricini }\end{array}$ & $86 a^{*}$ & $13 \mathrm{ab}$ & $85 \mathrm{a}$ & $13 b$ & $80 \mathrm{c}$ & $14 \mathrm{a}$ & $83 a$ & $11 \mathrm{~b}$ & $84 a$ & $17 \mathrm{a}$ \\
\hline Rizolex $^{\mathrm{a}}$-T & $86 a$ & $14 \mathrm{a}$ & $85 a$ & $13 \mathrm{~b}$ & $87 a$ & $14 \mathrm{a}$ & $85 a$ & $13 \mathrm{a}$ & $78 \mathrm{~b}$ & $12 b$ \\
\hline Untreated ${ }^{b}$ & $46 \mathrm{~d}$ & $5 \mathrm{~d}$ & $42 \mathrm{~d}$ & $5 \mathrm{~d}$ & $38 \mathrm{e}$ & $4 c$ & $37 f$ & $5 d$ & $59 c$ & $6 c$ \\
\hline
\end{tabular}

*Significant at 0.01 level of probability. a) Seeds were treated with rhizolex-T at rate of $2 \mathrm{~g} / \mathrm{kg}$ seeds. b) Seeds were treated with $0.01 \% \mathrm{MC}$ only.

Based on the in vitro and in vivo assessment, three strains; Streptomyces (25SA), Streptomyces (26SA) and Streptomyces toxytricini were evaluated for further studies of assessing their efficacy against damping-off disease under greenhouse conditions.

\section{Efficacy of Streptomyces Strains to Elicit Systemic Resistance Against Damping-off and Root-rot Diseases Under Greenhouse Conditions}

Data in table (5) indicate that seeds treated with Streptomyces strains individual or in combination and challenge inoculated with mixture of $F$. solani, F. oxysporum and Acremonium sp. induced significant disease protection compared with untreated treatment. The three Streptomyces strains significantly reduced damping-off incidence as well as root-rot incidence and severity (Table 5). In the present study, the results illustrate that, mixture of the three Streptomyces strains reduced pre-emergence by $6.5 \%$ and postemergence by $9.8 \%$, root-rot incidence by $25.2 \%$ and severity by 1.2 compared with untreated treatment and rizolex-T as a standard treatment (Table 5 and Fig. 3). These results agree with Sadeghi et al. (2017), who reported that, two Streptomyces isolates with the highest antagonistic activity, strains C 201 and C 801, reduced seedling damping-off of cucumber caused by Phytophthora drechsleri by 77 and $80 \%$, respectively, in artificially infested soils under greenhouse conditions. Moreover, figs. (2 and 3) illustrate that, the three Streptomyces strains have significant increase 
plant height and dry weight when applied individually or in combination. These results agree with the previous study of Singh et al. (2017) in which the authors illustrated the exploitation of actinomycetes in agricultural practices as biocontrol agents or biofertilizers for damping-off disease management and tomato crop improvement. Generally, plant growthpromoting organisms facilitate the plant growth directly by either assisting improved nutrition acquisition (nitrogen, phosphorus, potassium and essential minerals) or phytohormone production (IAA, cytokinins, gibberellins, etc.), or suppression of plant disease (Amaresan et al., 2018). Application of a mixture of three Streptomyces strains has resulted in much more intensive plant growth promotion and disease reduction when compared to strains tested individually (Fig. 2). This might be due to different mode of action for PGPR and related to sufficient root colonization and efficiency of biocontrol (El- Hadidy, 2012).

Table (5). Effect of Streptomyces strains as seed treatment on the incidence of quinoa damping-off and root-rot diseases under greenhouse conditions.

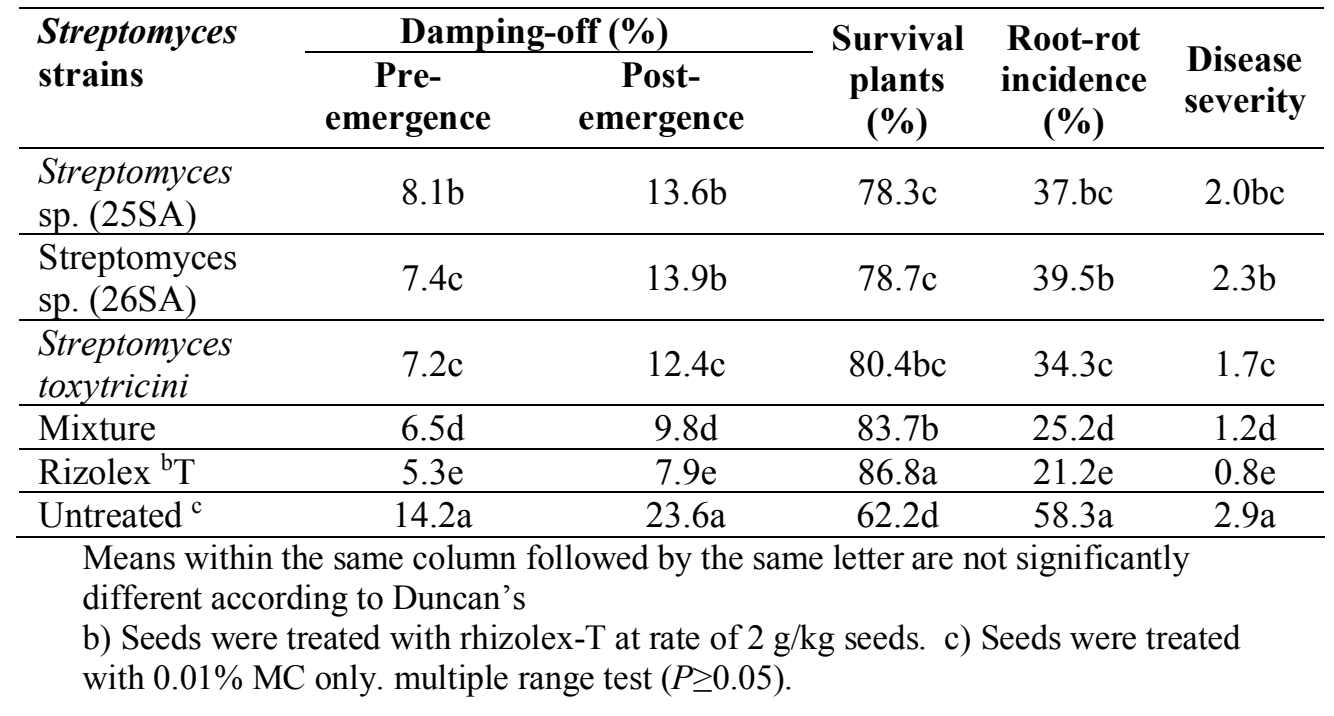




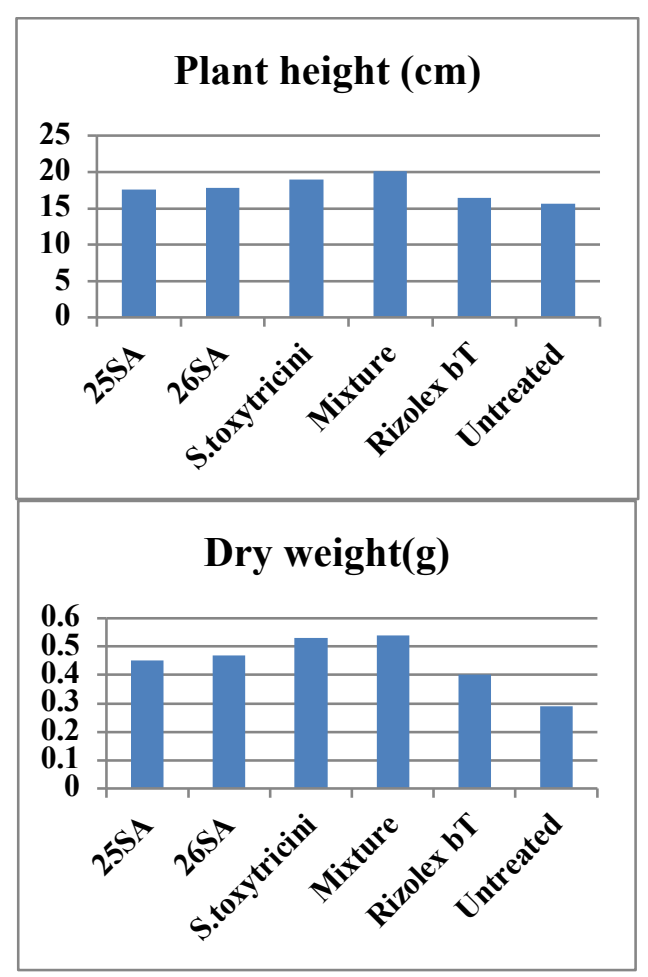

Fig. (2). Effect of Streptomyces strains on plant height and dry weight of quinoa plants.

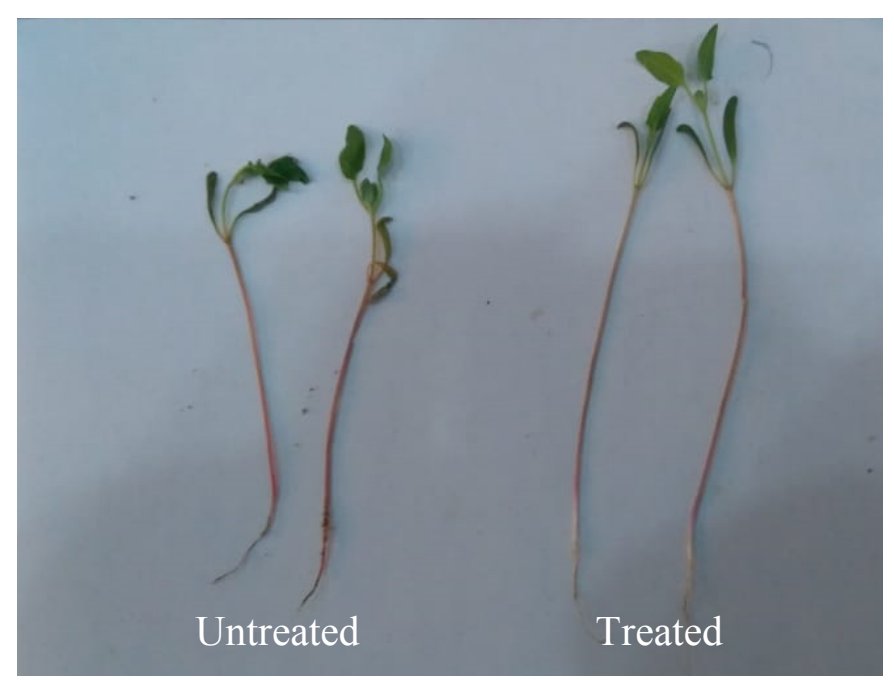

Fig. (3). Efficiency of the mixture of Streptomyces strains on root-rot suppression and growth promotion.

Egyptian J. Desert Res., 69, No. 1, 21-38 (2019) 


\section{Biological Changes Associated with Streptomyces Strains}

In the present study, seed treatment with Streptomyces strains resulted in increasing accumulation of phenolic substances in response to infection by the pathogen. The maximum phenolic content was observed in Streptomyces sp. (26SA) and S. toxytricini pretreated plants challenge inoculated with the pathogens. The higher amounts of phenolics were noticed even on $10^{\text {th }}$ day after the pathogens challenge. In plants inoculated with the pathogens alone, the phenolic content declined to the initial level on the $10^{\text {th }}$ day after inoculation. Plants treated with Streptomyces strains alone have increased content of phenolics compared to untreated plants (Table 6). Phenolic compounds may be fungitoxic in nature and may increase the mechanical strength of the host cell wall. Phenolic compounds, including flavonoids have important roles in plant defense against phytopathogens (Treutter, 2006). Soil inoculation with Phytophthora drechsleri and/or treatments with Streptomyces significantly resulted in increasing the accumulation of phenolic content in leaves of cucumber $12 \mathrm{~h}$ after inoculation compared to the control (Sadeghi et al., 2017). Table (7) indicates that, quinoa seeds treated with Streptomyces strains; Streptomyces sp. (26SA) and $S$. toxytricini induced plants to synthesize defense-related enzymes; peroxidase and chitinase. Whereas an additional increase in the synthesis was observed when pretreated plants challenged by inoculation with a mixture of pathogens; $F$. solani, F. oxysporum and Acremonum sp. The activity reached the maximum level on the $3^{\text {rd }}$ day after pathogens challenge and thereafter the activity remained at higher levels throughout the experimental period of 10 days. In plants treated with the pathogens alone, increased activity of peroxidase and chitinase was observed for period of 5 days and thereafter declined drastically in plant (Table 7). Treatment with the selected Streptomyces isolates enhanced the activities of defense related enzymes (Sunpapao et al., 2018) and increased activity of polyphenol oxidase and peroxidase enzymes (Sadeghi et al., 2017). As well as Streptomyces felleus YJ1 has strong antagonistic activity and ability to synthesize enhanced level of defense enzymes such as superoxide dismutase, peroxidase, poly phenol oxidase and phenylalanine ammonia lyase against Sclerotium sclerotiorum in oilseed rape under greenhouse conditions (Cheng et al., 2014). 
Table (6). Effect of Streptomyces strains on phenolic compounds in quinoa plants inoculated with mixture of pathogens; $F$. solani, $F$. oxysporum and Acremonium sp.

\begin{tabular}{lcccccc}
\hline & \multicolumn{3}{c}{ Total phenols $\left(\right.$ ug catechol mg protein $\left.{ }^{-1}\right)$} \\
\cline { 2 - 7 } Streptomyces strains & \multicolumn{3}{c}{ Without pathogen } & \multicolumn{3}{c}{ With pathogen } \\
\cline { 2 - 7 } & \multicolumn{3}{c}{ Period per days } & \multicolumn{3}{c}{ Period per days } \\
\cline { 2 - 7 } & $\mathbf{0}$ & $\mathbf{5}$ & $\mathbf{1 0}$ & $\mathbf{0}$ & $\mathbf{5}$ & $\mathbf{1 0}$ \\
\hline Streptomyces sp. (25SA) & 47 & 48 & 48 & 45 & 53 & 55 \\
Streptomyces sp. (26SA) & 55 & 52 & 50 & 58 & 90 & 86 \\
Streptomyces toxytricini & 52 & 50 & 50 & 55 & 88 & 85 \\
Untreated & 40 & 40 & 40 & 42 & 63 & 40 \\
\hline
\end{tabular}

Table (7). Effect of Streptomyces strains on peroxidase and chitinase activity in quinoa plants inoculated with mixture of $F$. solani, F. oxysporum and Acremonium sp. pathogens

\begin{tabular}{|c|c|c|c|c|c|c|c|c|c|c|c|c|}
\hline \multirow{4}{*}{ Streptomyces strains } & \multicolumn{6}{|c|}{ Peroxidase activity $\left(\min ^{-1} \mathrm{mg} \mathrm{protin}^{-1}\right)^{a}$} & \multicolumn{6}{|c|}{$\begin{array}{c}\text { Chitinase activity }\left(\min ^{-1}\right. \\
\left.\text { mg protin }^{-1}\right)^{b}\end{array}$} \\
\hline & \multicolumn{3}{|c|}{$\begin{array}{l}\text { Without } \\
\text { pathogen }\end{array}$} & \multicolumn{3}{|c|}{ With pathogen } & \multicolumn{3}{|c|}{$\begin{array}{l}\text { Without } \\
\text { pathogen }\end{array}$} & \multicolumn{3}{|c|}{$\begin{array}{c}\text { With } \\
\text { pathogen }\end{array}$} \\
\hline & \multicolumn{3}{|c|}{ Period per days } & \multicolumn{3}{|c|}{ Period per days } & \multicolumn{3}{|c|}{$\begin{array}{l}\text { Period per } \\
\text { days }\end{array}$} & \multicolumn{3}{|c|}{$\begin{array}{l}\text { Period per } \\
\text { days }\end{array}$} \\
\hline & $\mathbf{0}$ & 5 & 10 & $\mathbf{0}$ & 5 & 10 & $\mathbf{0}$ & 5 & 10 & $\mathbf{0}$ & 5 & 10 \\
\hline Streptomyces sp. (25SA) & 1.6 & 1.8 & 1.6 & 1.6 & 2.0 & 1.8 & 2 & 2 & 2 & 2 & 2.4 & 2.0 \\
\hline Streptomyces sp. (26SA) & 1.8 & 2.1 & 1.8 & 1.6 & 2.6 & 2.4 & 2 & 2 & 2 & 2 & 3.0 & 2.4 \\
\hline Streptomyces toxytricini & 1.8 & 2.3 & 1.9 & 1.6 & 2.4 & 2.2 & 2 & 2 & 2 & 2 & 2.8 & 2.6 \\
\hline Untreated & 1.6 & 1.6 & 1.6 & 1.6 & 1.6 & 1.6 & 2 & 2 & 2 & 2 & 2.4 & 2.0 \\
\hline
\end{tabular}

a) Peroxidase activity was determined in $1 \mathrm{~g}$ of quinoa roots and expressed as changes in the absorbance min $^{-1}$ mg protein ${ }^{-1}$ (Hammershmidt et al., 1982)

b) Chitinase activity was determined in $1 \mathrm{~g}$ of quinoa roots according to the colourimetric method suggested by Monreal and Reese (1969)

\section{REFERENCES}

Abdul Baki, A.A. and J.D. Anderson (1973). Vigor determination in soybean seed by multiple criteria. Crop Science, 13: 630-633.

Amaresan, N., K. Kumar, J.H. Naik, K.G. Bapatla and R.K. Mishra (2018). Streptomyces in Plant Growth Promotion: Mechanisms and Role. Actinobacteria: Diversity and Biotechnological Applications, pp. 125-135. In: "New and Future Development in Microbial Biotechnology and Bioengineering" (Singh, B.P., V.K. Gupta and A.K. Passari eds.) Elsevier, 362 pp.

Egyptian J. Desert Res., 69, No. 1, 21-38 (2019) 
Barakat, H., I. Khalifa, G.A. Ghazal, A. Shams, P.N. Denev (2017). Chemical composition and nutritional value of seeds from new quinoa accessions, cultivated in Egypt. Bulgarian Chemical Communications, 49 (Special Issue D): 231-238.

Beneduzi, A., D. Peres, L.K. Vargas, M.H. Bodanese-Zanettini and L.M.P Passaglia (2008). Evaluation of genetic diversity and plant growth promoting activities of nitrogen-fixing bacilli isolated from rice fields in south Brazil. Appl. Soil Ecol., 39 (3): 311-320.

Booth, C. (1971). The genus Fusarium. Commonwealth Mycological Institute, Kew Surrey, England, 235 pp.

Chaurasia, A., B.R. Meena, A.N. Tripathi, K.K. Pandey, A.B. Rai and B. Singh (2018). Actinomycetes: an unexplored microorganism for plant growth promotion and biocontrol in vegetable crops. World Journal of Microbiology and Biotechnology, 34: 132.

Cheng, G., F. Liu, Y. Huang, H. Yang, J. Yao, H. Shen and J. Xu (2014). Colonization of Streptomyces felleus YJ1 and its effects on disease resistant-related enzymes of oilseed rape. J. Agric, Sci., 6: 26-33.

Danielsen, S. and L. Munk (2004). Evaluation of disease assessment methods in quinoa for their ability to predict yield loss caused by downy mildew. Crop Prot., 23: 219-28.

Danielsen, S., A. Bonifacio and T. Ames (2003). Diseases of quinoa (Chenopodium quinoa). Food Rev. Int., 19: 43-59.

Domsch, K.H., W. Gams and T.H. Anderson (2007). Acremonium. In: "Compendium of Soil Fungi". Vol. 2. IHW-Verlag, Eching, Germany, p. 30-38.

Dřímalková, M. and K. Veverka (2004). Seedlings damping-off of Chenopodium quinoa Willd. Plant Protect. Sci., 40 (1): 5-10.

Duncan, D.B. (1955). Multiple range and multiple F tests. Biometrics, 11: 142.

Eisa, S., M.A. Eid, E.H. Abd El-Samad, S.A. Hussin, A.A. Abdel-Ati, N.E. El-Bordeny, S.H. Ali, Hanan M.A., A. Sayed, M.E. Lotfy, A.M. Masoud, A.M. El-Naggar and M. Ebrahim (2017). Chenopodium quinoa Willd. A new cash crop halophyte for saline regions of Egypt. Aust. J. Crop Sci., 11: 343-351.

El-Hadidy, A.M. (2012). Plant growth-promoting rhizobacteria (PGPR) induce cucumber root-rot protection under plastic tunnels conditions. Egyptian J. Phytopathol., 40 (2): 95-112.

El-Moity, T.H.A, H.B.M. Badrawy and A.M. Ali (2015). Survey on diseases and pests attack quinoa in Egypt. Sixth International Scientific Agriculture Symopsium, 15-18 October. Book of Proccedings, p. 868-876.

Filion, M., M. St-Arnaul and J abaji- Hare, S.H. (2003). Quantification of Fusarium solani f. sp. phasolina in mycorrhizal bean plants and surrounding mycorrhizosphere soil using real time polymerase chain 
reaction and direct isolations on selective media. Phytopathology, 93: 229-235.

Gams, W. (1975). Cephalosporium-like hyphomycetes: some tropical species. Trans. Br. Mycol. Soc., 64: 389-404.

Gordon, S.A. and R.P. Weler (1951). Colorimetric estimation of indoleacetic acid. Plant Physiol., 26 (1): 192-195.

Hammerschmidt, R., E.M. Nuckle and J. Kuc (1982). Association of enhanced peroxidase activity with induced systemic resistance of cucumber to Colletotrichum lagenarium. Physiological Plant Pathol., 20: 73-82.

Hassan, E.A., A.E.A. El Hadidy, N.M. Balabel, N.A. Eid and E.M. Ramadan (2018). Use of rhizobacteria as biocontrol agents against Ralstonia solanacearum: Principles, mechanisms of action and characterize its bioactive compounds. Current Sci. Int., 7 (2): 242-256.

ISTA (1993). Proceedings of International Seed Test Association. International rules for seed testing. Seed Sci. and Technol., 21: 1152.

Lamichhane, J.R., C. Dürr, A.A. Schwanck, M. Robin, J.P. Sarthou, V. Cellier, A. Messéan and J.N. Aubertot (2017). Integrated management of damping-off diseases. A review. Agron. Sustain. Dev., 37: 10.

Mahmoud, A.H. (2017). Production of quinoa (Chenopodium quinoa) in the marginal environments of South Mediterranean region: Nile Delta, Egypt. Egyptian J. Soil Sci., 57 (3): 329-337.

Monreal, J. and E.T. Reesa (1969). The chitinase of Serratia marcescens. Canadian J. Microbial, 15: 689-696.

Olanrewaju, O.S. and O.O. Babalola (2019). Streptomyces: implications and interactions in plant growth promotion. Applied Microbiol. Biotechnol., 103: 1179-1188.

Sadeghi, A., P. Koobaz, H. Azimi, E. Karimi and A.R. Akbari (2017). Plant growth promotion and suppression of Phytophthora drechsleri damping-off in cucumber by cellulase-producing Streptomyces. BioControl, 62: 805-819.

Senthilraja, G. (2016). Induction of Systemic Resistance in Crop Plants Against Plant Pathogens by Plant Growth-Promoting Actinomycetes. In: "Plant Growth Promoting Actinobacteria". Springer, p. 193-202.

Singh, S.P., R. Gupta, R. Gaur and A.K. Srivastava (2017). Antagonistic Actinomycetes mediated resistance in Solanum lycopersicon Mill. against Rhizoctonia solani Ku"hn. Proc. Natl. Acad. Sci., India, Section B: Biol. Sci., 87 (3): 789-798.

Singleton, L.L., J.D. Mihail and C.M. Bush (1992). In: "Methods for Research on Soil Borne Phytopathogenic Fungi". APS Press, St. Paul, M.N. USA, 265 pp.

Egyptian J. Desert Res., 69, No. 1, 21-38 (2019) 
Sunpapao, A., T. Chairin and S. Ito (2018). The biocontrol by Streptomyces and Trichoderma of leaf spot disease caused by Curvularia oryzae in oil palm seedlings. Biological Control, 123: $36-42$.

Thompson, D.C. (1996). Evaluation of bacterial antagonist for reduction of summer patch symptoms in Kentucky blue grass. Plant Disease, 80: $865-862$.

Treutter, D. (2006) Significance of flavonoids in plant resistance: a review. Environ. Chem. Lett., 4: 147-157.

Vidhyasekaran, P., K. Sethuraman, K. Rajappan and K. Vasumathi (1997). Powder formulations of Pseudomonas fluorescens to control pigeon wilt. Biological Control, 8: 166-171.

Vurukonda, S.S.K.P., D. Giovanardi and E. Stefani (2018). Plant growth promoting and biocontrol activity of Streptomyces spp. as endophytes. Int. J. Mol. Sci., 19: 952.

Yang, S.H., L. Zhang and J. Suh (2013). Effects of actinobacteria on plant disease suppression and growth promotion. Appl. Microbiol. Biotechnol., 97: 9621-9636.

Zieslin, N. and R. Ben-Zaken (1993). Peroxidase activity and presence of phenolic substances in peduncles of rose flowers. Plant Physiology and Biochemistry, 31: 333-339. 
تأثير عناصر المقاومة الحيوية على أمراض موت وأعفان الجذور لبادرات

$$
\text { قسبير المرسية النبات، مركد الحديديث الصحر اء، المطرية، القاهرة، مصر }
$$

Fusarium solani, Alternaria spp, Acremonium sp. في هذه الدراسة تم عزل بهرب F. oxysporum

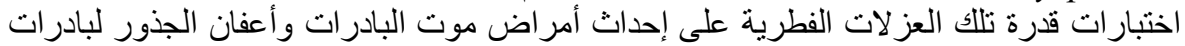

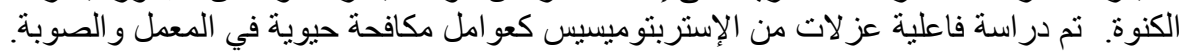

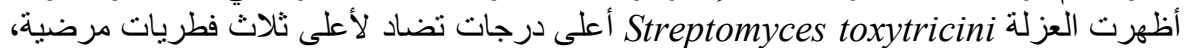

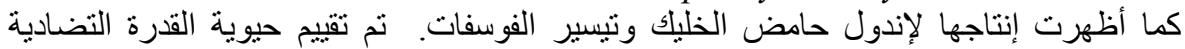

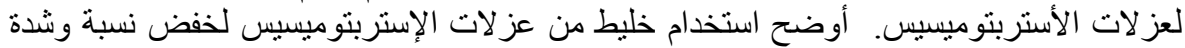

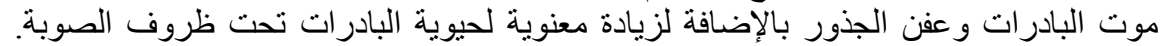

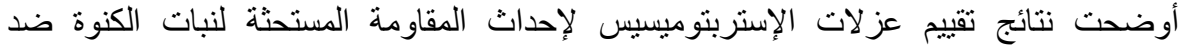

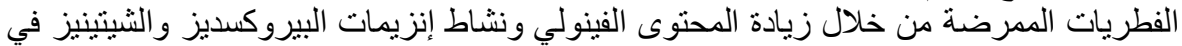
النباتات المعاملة بعز لات الإسنربتو ميسيس.

Egyptian J. Desert Res., 69, No. 1, 21-38 (2019) 